Intersectoral Dynamics and Economic Growth in Ecuador

Norbert M. Fiess

Dorte Verner
The frequent recommendation to exclude the oil sector from economic analysis may be short-sighted, as adverse shocks to the oil industry are likely to affect other sectors through the financial and public sectors, with which the oil sector has many links. There are also significant long-run relationships between the agricultural, industrial, and service sectors.

The World Bank

Latin America and the Caribbean Region

Economic Policy Sector Unit

January 2001 


\section{Summary findings}

Fiess and Verner analyze sectoral growth in Ecuador using multivariate cointegration analysis. They find significant long-run relationships between the agricultural, industrial, and service sectors. Moreover, they are able to derive dynamic sector models that combine the short-run links between the three sectors with long-run dynamics.

When they disaggregate the three sectors into their intrasectoral components, they discover many interesting relationships that contribute to a better understanding of inter- and intrasectoral dynamics in the context of Ecuadorian economic growth.

Their findings suggest that more attention should be paid to interdependencies in sectoral growth, since an improved understanding of intersectoral dynamics may facilitate the implementation of policy aimed at increasing economic growth in Ecuador.

There appears to be no direct link between the oil sector and the non-oil industrial sectors. But strong evidence supports cointegration between the oil industry and financial services as well as between the oil industry and public services. This means, among other things, that the oil sector cannot be excluded from intersectoral growth analysis, because an adverse shock to the oil industry is likely to affect other sectors through the financial sector, the public sector, or both.

This paper-a product of the Economic Policy Sector Unit, Latin America and the Caribbean Region-is part of a larger effort in the region to investigate intersectoral growth dynamics. Copies of the paper are available free from the World Bank, 1818 H Street NW, Washington, DC 20433. Please contact Anne Pillay, room 18-154, telephone 202-458-8046, fax 202522-2119, email address apillay@worldbank.org. Policy Research Working Papers are also posted on the Web at www.worldbank.org/research/workingpapers. The authors may be contacted at nfiess@worldbank.org or dverner@worldbank.org. January 2001. (29 pages)

The Policy Research Working Paper Series disseminates the findings of work in progress to encourage the exchange of ideas about development issues. An objective of the series is to get the findings out quickly, even if the presentations are less than fully polished. The papers carry the names of the authors and should be cited accordingly. The findings, interpretations, and conclusions expressed in this paper are entirely those of the authors. They do not necessarily represent the view of the World Bank, its Executive Directors, or the countries they represent. 


\title{
Intersectoral Dynamics and Economic Growth in Ecuador
}

\author{
Norbert M. Fiess Dorte Verner \\ World Bank \\ 1818 H Street \\ Washington, D.C. 20433 \\ U.S.A. \\ nfiess@worldbank.org \\ dverner@worldbank.org
}

The authors would like to thank Ana Lucia Armijos, Paul Beckerman, Hugh Blunch, Eliana Cardoso,

David Yuravlivker and an anonymous referee for helpful comments and suggestions. 



\section{Introduction}

The revival of growth theory during the past 15 years has also led to an expansion in empirical work on economic growth over the last decade. While the main focus in the empirical growth literature is on the determinants of aggregate economic growth, less emphasis has so far been placed on sectoral economic growth.

The sectoral growth literature builds mainly on the dual economy model originating in Lewis (1954), Fei and Ranis (1961) and Sen (1966). This model seeks to explain economic growth by emphasising the roles of agriculture and industry and the interplay between them. ${ }^{1}$ The dual economy model views the agricultural sector as the basis of an emerging economy, a generator of the capital necessary for take-off towards the second stage of economic development: industrialisation. Once industrialisation has taken place, the agricultural sector becomes gradually a mere appendage to the economic system, with no internal economic integration and a low degree of intersector linkages.

The dual economy literature generally rules out two major issues about the later stages. First, the literature denies that agriculture may be an important growth-promoting factor. Second, it rules out feedback mechanisms between agriculture and industry.

Recent developments in the sectoral growth literature dispute this view of the dual economy model. Mellor and Lele (1970), Mellor (1972), Johonston and Kilby (1975) argue that a virtuous cycle between agricultural intensification and non-agricultural activity could emerge on the basis of production and consumption linkages. An increased demand of farmers for inputs such as machinery and machinery repair can stimulate nonagricultural activity through backward linkages. Non-agricultural activity could be stimulated by agriculture at the same time via forward linkages such as the requirement to process agricultural products through spinning, milling or canning.

Gopinath, Roe and Shane (1996) analyse the possible link between agriculture and food processing and find that productivity gains in agriculture feed back into the food processing industry, where they lead to cheaper inputs. Lower priced inputs lead in turn to increased derived demand for primary agricultural products, thus partly mitigating the price decline. The two sectors evolve interdependently over time, contrary to what the dual economy model predicts.

\footnotetext{
1 For references to studies that build upon the framework along the lines of the classical dualistic framework, see Blunch and Verner (1999).
} 
Blunch and Verner (1999) present evidence from a sectoral growth analysis in three African countries and find long-run relationships and short-run causality between the industrial, agricultural and service sectors.

The empirical evidence of high interdependence between agriculture and other economic sectors is interesting, since agriculture is generally assigned a low degree of sector interdependence and thus rarely seen as a key sector for economic development (Chenery and Watanabe (1958) and Hirschman (1961)).

The agricultural sector with its exports of bananas, shrimps cocoa and has traditionally played an important part in the economic development of Ecuador. In the 1990s cut flowers also became an important export commodity. The recent experience with the trade liberalisation, implemented at the end of the $1980 \mathrm{~s}$, indicates further that Ecuador's export diversification has been dominated by processed goods which are intimately related to natural resources such as marine products or raw or processed food products and not by industrial exports (Michaely, 1999). Since this development in particular underlines the high degree of interdependence between agricultural and industrial output for the Ecuadorian economy, it is the aim of this paper to quantify these intersector dynamics.

The emphasis in this paper is mostly on identifying intersector growth dynamics using advanced data analysis techniques and less on explaining the determinants of growth. Identifying main lines of causality and intersector linkages can help policy makers to obtain a better understanding of the economic growth process in Ecuador and to formulate more effective development strategies. It also provides useful information for future economic modeling of intersector growth.

The remainder of this paper is organised as follows. Section 2 presents a brief country profile of Ecuador and attempts to place the present analysis into an historic context. Section 3 describes the data and the econometric methodology. Section 4 presents the empirical findings and, finally, section 5 presents the main conclusions. 


\section{A country profile of Ecuador}

The nationalisation of the oil industry in 1972 and the oil boom in the 1970s turned Ecuador from a poor, primary-export dependent economy into a middle-income country with a stock of wealth in the form of oil reserves.

The industrialisation strategy of the 1970s was highly protective in nature and led to a capital-intensive industry, which produced inefficiently when compared internationally. As a result, most capital goods, for the purpose of investment, as well as most intermediate goods were imported, while the domestic capital goods production remained small and concentrated in low-technology intensive processes. In the years prior to the debt crisis Ecuador imported more than two-thirds of all installed machinery (see Hentschel, 1994).

The outbreak of the debt crises in 1982, which halted international capital flows to most developing countries, brought for Ecuador a high degree of macroeconomic instability, which persisted through the majority of the 1980s. The economy was further disrupted by a major earthquake in 1987 , which destroyed the national oil pipeline and halted oil exports for 5 months.

The end of the 1980s brought a change in the development model towards exportdiversification and trade liberalisation, with the result of a rapid and comprehensive trade liberalisation between 1989 and 1992, the adoption of the common external tariff of the Andean Group and the opening of the frontier with Colombia. The late 1980s and early 1990 s also saw a substantial reduction in public consumption, the elimination of many implicit and explicit state subsidies and a liberalisation of interest rates (see Marconi and Samaniego, 1995).

Even though Ecuador's economy is highly concentrated, with oil, bananas and shrimps representing the major export commodities, the recent trade liberalisation brought a slight change in the structure of Ecuador's exports. While the three major export commodities accounted for $85 \%$ of aggregate exports in the late 1980s and early 1992, their combined share dropped to $70 \%$ in 1996-97 (Michaely, 1999). According to Michaely (1999), the export diversification of Ecuador has been dominated by processed goods which are intimately related to natural resources such as marine products or raw or 
processed food products and not by industrial exports. ${ }^{2}$ This underlines the general importance of the agricultural sector for the development of other sectors and as a potential source of growth in Ecuador.

Table 1:

\begin{tabular}{|c|c|c|c|c|c|c|}
\hline \multicolumn{7}{|c|}{ Contribution to GDP in percentage share of total GDP } \\
\hline & 1965 & 1970 & 1973 & 1980 & 1990 & 1998 \\
\hline Agriculture & 25.78 & 24.97 & 18.09 & $\mathbf{1 4 . 3 6}$ & $\mathbf{1 7 . 6 7}$ & $\mathbf{1 7 . 2 8}$ \\
\hline Industry & 22.30 & 24.19 & 39.22 & 33.80 & 31.74 & 32.96 \\
\hline -Oil & & & 19.38 & 10.21 & 11.81 & 13.52 \\
\hline - Manufacturing & 15.23 & 17.17 & 14.11 & 18.16 & 15.45 & 15.48 \\
\hline - Electricity & $\overline{0.59}$ & 0.76 & 0.67 & 0.76 & 1.53 & 1.40 \\
\hline - Construction & 6.49 & 6.26 & 5.07 & 4.68 & 2.94 & 2.56 \\
\hline Services & 47.64 & $\mathbf{5 0 . 3 3}$ & 40.14 & $\mathbf{5 0 . 0 2}$ & 48.96 & $\mathbf{4 8 . 6 7}$ \\
\hline - Commerce & 14.83 & 14.81 & 12.39 & 14.66 & 13.35 & 13.52 \\
\hline - Transport & 4.00 & 5.36 & 4.53 & 6.11 & 6.17 & 6.25 \\
\hline - Financial & 1.72 & 2.46 & 2.22 & 3.88 & 2.36 & 3.55 \\
\hline - Other (non-governmental) & 18.96 & 18.15 & 14.27 & 16.08 & 18.25 & 18.53 \\
\hline - Government & 8.12 & 9.55 & 6.72 & 9.29 & 8.82 & 6.81 \\
\hline
\end{tabular}

Source: Banco del Ecuador

2 Table A6 in the appendix lends further evidence to this point and shows that exports are mainly primary or semi-industrialized. 
Figure 1: Sectoral development in GDP (1965 - 98)

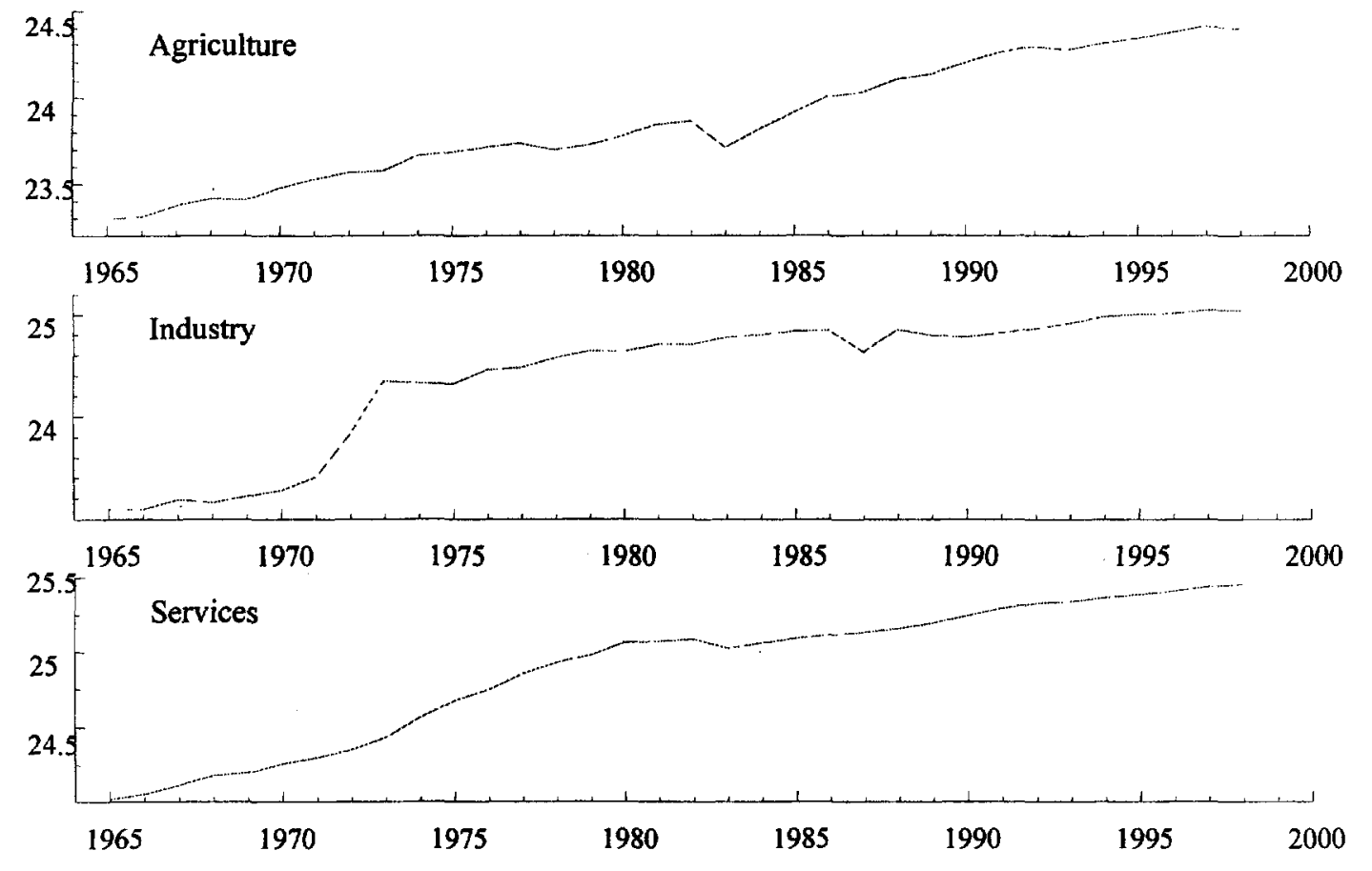

Source: Banco del Ecuador

\section{Data and Methodology}

\section{Data Description}

The data used in this study consists of quarterly data for real GDP in the industrial (Ind), agricultural (Agr) and service (Ser) sectors from 1965 to 1998 . The data was provided by the Banco del Ecuador. The three series are depicted in log-levels in Figure 1 and show an increase over the whole sample.

The industrial GDP series is marked by one large jump, caused by the rapid increase in industrial output after the foundation of a national oil industry in 1972. In March 1987 industrial GDP fell temporarily due to a major earthquake, which destroyed the export oil pipeline and halted oil exports for 5 months. The drop in the agricultural GDP series in 1983 is caused by the adverse impact of the natural phenomena of El Niño.

Table 1 presents the contribution of the different sectors in percentage shares of total GDP at various points in time. When comparing the contribution of the sectors to the total GDP across time, it appears that the weight of the agricultural sector declined from $25.8 \%$ in 1965 to $17.3 \%$ in 1998 , while the industrial sector managed to increase its 
share in the same time from $22.3 \%$ in 1965 to $33 \%$ in 1998 . Once we disaggregate the industrial sector, we find that the increasing weight of the industrial sector can be largely attributed to the oil industry. The share of the manufacturing sector appears to have remained largely constant, averaging around $15 \%$ of total GDP, while construction effectively reduced its share in total GDP from $6.5 \%$ to $2.6 \%$.

The aggregated service sector managed to keep a constant share of total GDP of just below $50 \%$. However, the disaggregation of the service sector shows a different picture. While the weight of public sector services declined from $8.1 \%$ in 1965 to $6.8 \%$ in 1998 , the financial service sector managed to more than double its contribution to total GDP from $1.7 \%$ in 1965 to $3.6 \%$ in 1998 . The transport sector also steadily increased its share in total GDP from $4.0 \%$ in 1965 to $6.3 \%$ in 1998 .

\section{Methodology}

All time series were log-transformed and tested for unit roots. Based on the augmented Dickey-Fuller (ADF) unit root test all series appear $I(1)$ in levels and $I(0)$ in first differences. See Table A1 in the appendix for a summary of the unit root tests. Since nonstationary variables might cointegrate to form a stable long-run relationship, we use the multivariate Johansen approach (1988) to explore possible cointegration relationships in the data. ${ }^{3}$ We intend to interpret cointegration as evidence for interdependence between the different sectors and propose to explore the dynamics and linkages between the sectors further by estimating dynamic models which incorporate short- as well as long-run information.

\footnotetext{
${ }^{3}$ Appendix 1 provides a brief review of the multivariate Johansen (1988) approach.
} 


\section{Empirical Findings}

Section 4.1 present the results of a cointegration analysis over the whole sample (1965:Q1 to 1998:Q4) using quarterly real GDP data provided by the Banco de Ecuador. To test the robustness of our findings, we additionally investigate two different subsamples. Section 4.2 concentrates on the period from 1965:Q1 to 1989:Q4, section 4.3 focuses on the period from 1990:Q1 to $1998: Q 4$. Section 4.4 estimates a dynamic shortrun sector growth model based on the results of section 4.3. Section 4.5 disaggregates the industrial, agricultural and service sectors into their components and presents the evidence of bivariate cointegration tests between different intrasector components. Appendix 2 repeats parts of the analysis of section 4 for an alternative data set, using annual real GDP data from the World Bank Latin American and Caribbean Regional Database.

\subsection{Evidence of Cointegration}

Our sectoral growth VAR model includes a constant in the cointegration space and 4 lags of each of the variables industrial, agricultural and service sector GDP. This is sufficient to produce random errors. ${ }^{4,5}$

\footnotetext{
${ }^{4}$ The deterministic components of the VAR were defined according to the rank test based on the so-called Pantula principle (see Johansen and Juselius (1992). According to the Pantula principle three different model specifications (no linear trends in the levels of the data (Model 2), linear trends in the levels of the data (Model 3) and time-trend in the cointegration space (Model 4)) are estimated and the results are presented from the most restrictive alternative (i.e. $r=0$, and Model 2) through to the least restrictive alternative (, i.e. $r=n-1$, and Model 4). The critical values for Model 2, Model 3 and Model 4 correspond to Table $1^{*}$, Table 1 and Table $2^{*}$ in Osterwald-Lenum (1992). The test procedure according to the Pantula principle is then to move through Table Al from the most restrictive model and at each stage to compare the trace test statistics to its critical value and only stop the first time the null hypothesis is not rejected.

In our case, this is for $r=1$ and Model 2. The rank test thus suggests the inclusion of a constant in the cointegration space.

${ }^{5}$ The model specification is presented in the appendix in Table A3. The diagnostics on the residuals of the system show the absence of autocorrelation but indicate some non-normality. Since Cheung and Lai (1993) have shown that the trace-test is robust to both skewness and excess kurtosis, we decided to estimate the model with this specification.
} 
Table 2:

\begin{tabular}{lllll}
\hline $\begin{array}{l}\text { Null } \\
\begin{array}{l}\text { Hypothesis } \\
\mathrm{H}_{0} \text { : rank }=r\end{array}\end{array}$ & $\begin{array}{l}\text { Alternative } \\
\text { Hypothesis }\end{array}$ & $\begin{array}{l}\text { Lag: 4 } \\
\text { With Constant }\end{array}$ & $\begin{array}{l}95 \% \\
\text { Critical } \\
\text { Value }\end{array}$ & $\begin{array}{l}90 \% \\
\text { Critical Value }\end{array}$ \\
\hline $\begin{array}{lllll}\lambda_{\text {trace }} \text { test } \\
r=0\end{array}$ & $r>0$ & $45.84^{\circ}$ & 35.10 & 31.88 \\
$r \leq 1$ & $r>1$ & 13.48 & 20.17 & 17.79 \\
$r \leq 2$ & $r>2$ & 4.02 & 9.10 & 7.50 \\
\hline
\end{tabular}

*Rejection at the $5 \%$ level of significance

Source: Authors' calculations.

The estimates of trace test statistics, $\lambda_{\text {trace, }}$ which test the hypothesis of less than or equal to $r$ cointegrating vectors are reported in Table 2 . The number of cointegrating vectors is determined by starting at the top of Table 2 and moving down until $\mathrm{H}_{0}$ cannot be rejected. Since the trace-test statistics for the null hypothesis of no-cointegration $\left(\lambda_{\text {trace }}=45.84\right)$ exceeds its $95 \%$-critical value of 35.10 , but the null hypothesis of $r \leq 1$ cannot be rejected, there appears to be evidence for one cointegrating relationship between the industrial, the agricultural and the service sectors. ${ }^{7}$

The Ecuadorian economy has been subjected to frequent and substantial external (e.g., oil boom, debt crisis and natural disasters) and internal shocks (e.g., changes in the development model) during the 1965 to 1998 period. Therefore, empirical evidence in favour of one stable long-run relationship describing the sectoral growth dynamics of Ecuador would be a surprising result.

To address the issue of stability of the cointegration relationship over time, we perform a recursive cointegration analysis, where the trace-statistics for the hypothesis of less than one cointegration vector is estimated for different sample periods.

Operationally, the data from 1965:Q1 to 1982:Q1 (roughly the first half of the sample) is used as a base period for the calculation of the first test statistic and the sample

\footnotetext{
${ }^{6}$ This result comes about by starting at the top of Table 1 and moving downwards until $\mathrm{H}_{0}$ cannot be rejected. As this is the case in the second row, the analysis maintains the $\mathrm{H}_{0}$ of zero cointegrating vectors, this implies the existence of exactly one cointegrating vector in the data.

7 The World Bank Latin American and Caribbean Regional Database contains data on annual real GDP from 1965-98 for Ecuador. Since this data base could have been used for our cointegration analysis, we perform additionally a cointegration analysis using this data set (see Appendix 2). This allows us to contrast the results of a cointegration analysis based on annual data with the results of a cointegration analysis using a higher frequency. Since cointegration is a long-run property, the frequency of the data should not matter and we would expect to find similar results. As Appendix 2 shows, this appears to be the case.
} 
size is then successively increased by one observation at a time until the end of the sample.

The corresponding trace-statistics are plotted in Figure 2. The graph is scaled such that unity corresponds to the $10 \%$ level of significance. As can be seen from Figure 2 , the trace-test statistic rejects the hypothesis that the rank is null only from the late $1980 \mathrm{~s}$ onwards. Thus, only from approximately 1990 does there seem to be a common stochastic trend between the three sectors. Prior to that there appears to be no evidence for cointegration between the three sectors. To investigate this apparent break in the sample further, we split the sample into the period prior to and post 1990 and perform two separate cointegration analyses.

Figure 2: Recursive trace test for cointegration between agricultural, industrial and service sector GDP 1965 - 1998)

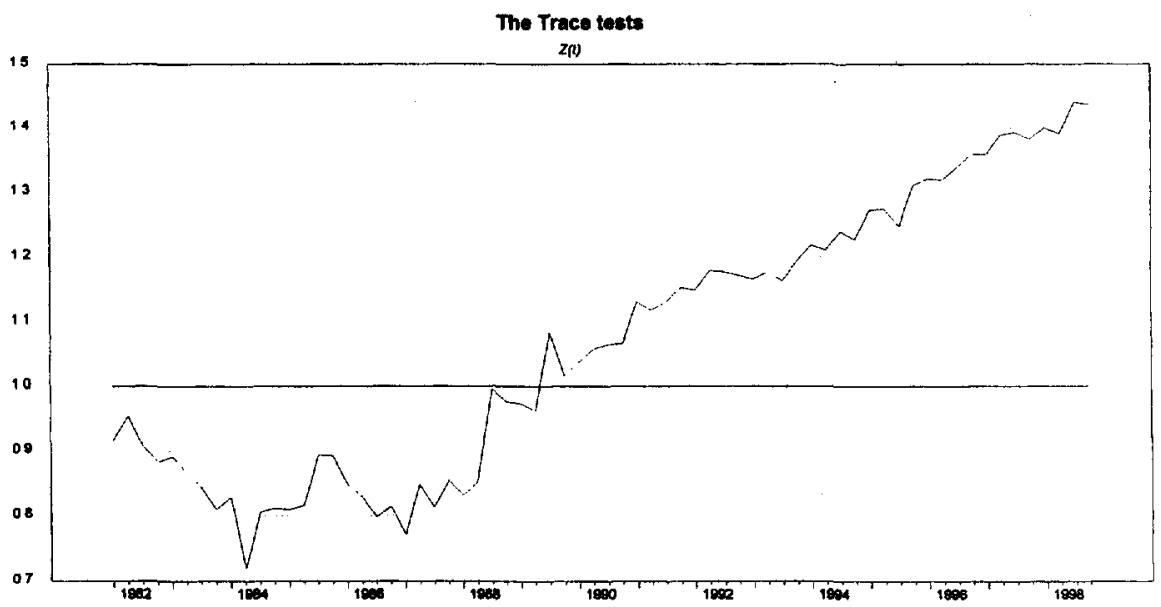

\subsection{The sample from 1965:01 to 1989:04}

When estimating a VAR from 1965:04 to 1989:04, non-normality is strongly rejected for the industry GDP series. An analysis of the residuals indicates that the non-normality is due to two large jumps in the series. These may be caused by the rapid increase in industrial output after the foundation of a national oil industry in 1972 and by the aftermath of a major earthquake in March 1987, which destroyed the export oil pipeline and halted oil exports for 5 months. The rapid increase of industrial output after 1972 as well as the 1987 earthquake represent large outliers and could bias the outcome of our 
cointegration analysis and explain the lack of cointegration prior to 1990 . We therefore report the findings for four different subsamples and test for cointegration between the three sectors inclusive and exclusive of the oil industry. The four different subsamples are 1965:Q1 to 1986:Q4 1965:Q1 to 1989:Q4, 1973:Q1 to 1986:Q4, 1973:Q1 to 1989:Q4 and the findings of the individual cointegration tests are reported in column III (inclusive oil) and column IV (exclusive oil) in Table 3.

The findings of the different tests reveal an unanimous picture. The findings are unaffected if the oil industry is included or excluded from the analysis. And even if we exclude the time period prior to the foundation of the national oil industry or post the 1987 earthquake, we fail to establish a cointegration relationship in the data prior to 1990 .

Table 3: Cointegration tests for different subsamples

\begin{tabular}{|c|c|c|c|c|c|}
\hline $\begin{array}{l}\text { Null } \\
\text { Hypothesis }\end{array}$ & $\begin{array}{l}\text { Alternative } \\
\text { Hypothesis }\end{array}$ & $\lambda_{\text {trace }}$ & $\begin{array}{c}\lambda_{\text {trace }} \\
\text { (excl. oil) }\end{array}$ & $\begin{array}{l}95 \% \\
\text { Critical } \\
\text { Value }\end{array}$ & $\begin{array}{l}90 \% \\
\text { Critical } \\
\text { Value }\end{array}$ \\
\hline $\mathrm{I}$ & II & III & IV & $\overline{\mathrm{V}}$ & VI \\
\hline \multicolumn{6}{|c|}{ 1965Q1 - 1989Q4 } \\
\hline \multicolumn{6}{|l|}{$\lambda_{\text {trace }}$ test } \\
\hline$r=0$ & $r>0$ & 32.38 & 25.87 & 35.10 & 31.88 \\
\hline$r \leq 1$ & $r>1$ & 9.90 & 12.33 & 20.17 & 17.79 \\
\hline$r \leq 2$ & $r>2$ & 2.70 & 4.24 & 9.10 & 7.50 \\
\hline \multicolumn{6}{|c|}{$1973 Q 1-1989 Q 4$} \\
\hline$\lambda_{\text {trace }}$ test & & & & & \\
\hline$r=0$ & $r>0$ & 34.36 & 27.64 & 35.10 & 31.88 \\
\hline$r \leq 1$ & $r>1$ & 16.61 & 15.27 & 20.17 & 17.79 \\
\hline$r \leq 2$ & $r>2$ & 3.79 & 3.91 & 9.10 & 7.50 \\
\hline \multicolumn{6}{|c|}{$1965 Q 1-1986 Q 4$} \\
\hline$\lambda_{\text {trace }}$ test & & & & & \\
\hline$r=0$ & $r>0$ & 25.97 & 26.20 & 35.10 & 31.88 \\
\hline$r \leq 1$ & $r>1$ & 10.13 & 11.31 & 20.17 & 17.79 \\
\hline$r \leq 2$ & $r>2$ & 2.99 & 3.21 & 9.10 & 7.50 \\
\hline \multicolumn{6}{|c|}{ 1973Q1 - 1986Q4 } \\
\hline$\lambda_{\text {trace }}$ test & & & & & \\
\hline$r=0$ & $r>0$ & 30.20 & 31.76 & 35.10 & 31.88 \\
\hline$r \leq 1$ & $r>1$ & 14.24 & 12.76 & 20.17 & 17.79 \\
\hline$r \leq 2$ & $r>2$ & 4.72 & 3.82 & 9.10 & 7.50 \\
\hline
\end{tabular}

Source: Authors' calculations. 


\subsection{The sample from 1990:01 to 1998:04}

Since the recursive cointegration analysis from 1965 to 1998 indicates at least one cointegration relationship from 1990 onwards, we focus in this section on the period from 1990:Q1 to 1998:Q4.

When re-examining our model specification, we find that a lag length of 2 is now sufficient to produce random errors. The model mis-specification tests are presented in Table A4 in the appendix. The $\lambda_{\text {trace }}$ test indicates one significant cointegrating vector.

Table 4

\begin{tabular}{lllll}
\hline $\begin{array}{l}\text { Null } \\
\text { Hypothesis }\end{array}$ & $\begin{array}{l}\text { Alternative } \\
\text { Hypothesis }\end{array}$ & $\begin{array}{l}\text { Lag: } 2 \\
\text { With Constant }\end{array}$ & $\begin{array}{l}95 \% \\
\text { Critical Value }\end{array}$ & $\begin{array}{l}90 \% \\
\text { Critical Value }\end{array}$ \\
\hline$\lambda_{\text {trace }}$ test & & & & \\
$r=0$ & $r>0$ & $41.81^{*}$ & 35.10 & 31.88 \\
$r \leq 1$ & $r>1$ & 17.38 & 20.17 & 17.79 \\
$r \leq 2$ & $r>2$ & 2.89 & 9.10 & 7.50 \\
\hline
\end{tabular}

"Rejection at the $5 \%$ level of significance

Source: Authors' calculations,

Normalising the cointegration vector on the $3^{\text {rd }}$ element, yields the following estimates for $\beta$ (Table 5) and $\alpha$ (Table 6):

Table 5

\begin{tabular}{ll}
\hline & $\beta$ \\
\hline Agr & 1.000 \\
Ind & 0.077 \\
Ser & -0.722 \\
Constant & -2.588 \\
\hline
\end{tabular}

Source: Authors' calculations.

Table 6

\begin{tabular}{lll}
\hline & $\alpha$ & t-statistics \\
\hline$\Delta$ Agr & -0.176 & -3.997 \\
$\Delta$ Ind & -0.182 & -2.723 \\
$\Delta$ Ser & -0.138 & -3.374 \\
\hline
\end{tabular}

Note: $\Delta$ indicates a variable in first differences.

Source: Authors' calculations.

The column of $\beta$ is the cointegrating parameter vector or, in other words $\beta$ spans the cointegration space. The coefficients of $\alpha$ can be interpreted as adjustment coefficients measuring the relative importance of a deviation from equilibrium on a given 
endogeneous variable. Since $\Delta A g r, \Delta I n d$ and $\Delta S e r$ all have significant adjustment coefficients, all three variables adjust to a disturbance in the cointegration relationship.

Since it is now common practice to try to identify the cointegration space, we impose restrictions on the cointegration vector to see if one of the three variables can be excluded from the cointegration space. From the point of view of a dual economy model (Lewis (1954), Fei and Ranis (1961) and Sen (1966)) such a test might seem important. As mentioned earlier, the dual economy model rules out a long-run relationship between agricultural and industrial outputs. Thus, only if $\mathrm{Agr}$ and Ind are both part of the cointegration space, are we able to support a long-run relationship between the agricultural and the industrial sectors and take it as evidence against the dual economy model. If we cannot exclude one of the two series from the cointegration space, the resulting cointegration relationship indicates a long-run relationship between the agricultural or the industrial sectors and the service sector, but not between the agricultural and industrial sectors. This would then not necessarily indicate a violation of the dual economy model.

The results of the different hypotheses tests are summarised in Table 7. Since a joint test of long-run exclusion and weak-exogeneity is rejected for $\mathrm{Agr}$, Ind and Ser, all three variables are needed to form the long-run relationship. None of the sectors can therefore be excluded from the cointegration relationship or even be treated as weakly exogenous to the system of equations. 
Table 7

\begin{tabular}{|l|l|l|l|l|l|l|}
\hline & Agr & Ser & Ind & Const. & LR-test & p-value \\
\hline $\boldsymbol{H}_{1}$ & 0 & 1 & $*$ & $*$ & $\chi^{2}(2)=10.17$ & 0.01 \\
\hline $\mathrm{H}_{2}$ & 1 & 0 & $*$ & $*$ & $\chi^{2}(2)=12.27$ & 0.00 \\
\hline $\mathrm{H}_{3}$ & 1 & $*$ & 0 & $*$ & $\chi^{2}(2)=6.21$ & 0.04 \\
\hline $\boldsymbol{H}_{4}$ & 1 & $*$ & $*$ & 0 & $\chi^{2}(1)=0.90$ & 0.34 \\
\hline
\end{tabular}

Note: Table 7 summarises the findings of different hypotheses tests on the coefficients of $\alpha$ and $\beta$. A 0 indicates that the coefficient of a variable, $i$, has been restricted to zero and is equivalent to a test of longrun exclusion, a 1 indicates the variable used for normalisation and a $*$ indicates that a variable has been left unrestricted. All tests are joint tests for long-run exclusion and weak exogeneity, i.e., $\alpha_{i}=\beta_{i}=0$.

All tests are likelihood ratio (LR) tests which are distributed as $\chi^{2}$, conditional upon the rank and the number of restrictions imposed.

Source: Authors' calculations.

Since $H_{4}$ cannot be rejected, which says that the constant can be excluded from the cointegration space and, when normalising on service sector GDP, Ser, the long-run reduces to:

$$
\text { Ser }=0.747 * A g r+0.339 * \text { Ind }
$$

\subsection{A Dynamic Short-run Growth model}

To combine short-run and long-run information for the three sectors in a growth model we estimate a parsimonious dynamic model, which contains the cointegration relationship and up to $1 \mathrm{lag}$ of $\mathrm{Ind}, \mathrm{Agr}$ and $\mathrm{Ser}$ in first differences. ${ }^{8}$ Following Hendry's general-to-specific system reduction approach all insignificant variables are removed from the system based on $F$-tests and the resulting system is then estimated by full information maximum likelihood (FIML) to further improve its robustness. The resulting model is presented in Table 8.

The final model passes the Hendry-Mizon LR test of over-identifying restrictions, $\chi^{2}(3)=3.4835[\mathrm{p}=0.3229]$, and therefore represents a valid reduction of the initial system. All variables that appeared to be strongly significant in the long-run, also retain -

\footnotetext{
${ }^{8}$ A specification of 1 lag is adequate because the two lags in levels used for the cointegration analysis correspond to one lag in first-order differences.
} 
with the exception of $\Delta I n d_{t-1}$ - their significance in the short-term. Industrial growth only seems to have a direct positive impact on service sector growth.

Table 8: Dynamic Short-Run Sector Growth Model (FIML estimation)

\begin{tabular}{|c|c|c|c|c|c|c|c|}
\hline & $\Delta \mathrm{Agr}_{\mathrm{t}}$ & $\Delta$ Ind $_{t}$ & $\Delta \operatorname{Ser}_{t}$ & $\Delta \mathrm{Agr}_{t-1}$ & $\Delta \operatorname{Ind}_{t-1}$ & $\Delta \operatorname{Ser}_{t-1}$ & $\mathrm{CI}_{\mathrm{t}-1}$ \\
\hline$\Delta \mathbf{A g r}_{\mathbf{t}}$ & -1 & & & & & $\begin{array}{l}-0.33381 \\
(-1.874)\end{array}$ & $\begin{array}{l}0.34612 \\
(4.471)\end{array}$ \\
\hline$\Delta$ Ind $_{t}$ & & -1 & & $\begin{array}{l}0.94599 \\
(3.805)\end{array}$ & & $\begin{array}{l}-0.72683 \\
(-2.272)\end{array}$ & $\begin{array}{l}0.19976 \\
(1.497)\end{array}$ \\
\hline$\Delta$ Ser $_{t}$ & & & -1 & $\begin{array}{l}0.24592 \\
(1.679)\end{array}$ & $\begin{array}{l}0.16285^{* *} \\
(2.005)\end{array}$ & $\begin{array}{l}-0.53421 \\
(2.908)\end{array}$ & $\begin{array}{l}0.18986 \\
(-2.814)\end{array}$ \\
\hline $\begin{array}{l}\text { Diagnostics } \\
\text { Single Equatio, } \\
\Delta \text { Agr } \\
\Delta \text { Ind } \\
\Delta \text { Ser } \\
\text { Vector Analysi }\end{array}$ & & $\begin{array}{l}\delta \\
0.01264 \\
0.02155 \\
0.01201 \\
\mathrm{~F}_{\text {arr }}(18,71) \\
\chi_{\text {norm }}^{2}(6) \\
\mathrm{F}_{\text {arch }}(84,\end{array}$ & $\begin{array}{l} \\
1.4329 \\
5.353 \\
=0.8523\end{array}$ & $\begin{array}{l}F_{\mathrm{w}}(2,30) \\
0.736 \\
1.585 \\
4.007^{*}\end{array}$ & $\begin{array}{l}\chi_{\text {narmal }}^{2}(2) \\
1.841 \\
1.668 \\
2.272\end{array}$ & $\begin{array}{l}F_{\text {arch }}(1,30) \\
3.615 \\
1.139 \\
1.037\end{array}$ & \\
\hline
\end{tabular}

*Rejection at a 5 percent level of significance.

Note: Values in parentheses are $t$-statistics. $\Delta$ indicates a variable in first differences, subscripts denotes the time period, i.e., $t$ : current period, $t-1$ : lagged one period, $\mathrm{CI}$ denotes the restricted cointegration relation.

Source: Authors' calculations

The agricultural sector seems to play a major role in determining growth in the other two sectors. The strong positive growth effect of agriculture on the industrial sector is of particular interest since it indicates direct Granger causality from agriculture to industry. An explanation for the direct linkage between the agricultural and industrial sector could be provided by the fact that the marine product and processed food industry, which depends directly on agriculture and fishing, managed to increase their overall export shares substantially over recent years.

While there appears to be a direct impact of agricultural growth on industrial growth, the industrial sector affects the growth of the agricultural sector only indirectly via the error correction term and via the growth equation of the service sector, $\Delta \operatorname{Ser}_{t-1}$.

Growth in the agricultural sector also seems to positively affect growth in the service sector, possibly indicating an increase in commerce with agricultural produces. 
The service sector seems also to have an important impact on the growth in the other two sectors. But, its impact on growth in the industrial as well as the agricultural sectors is negative.

Analysing GDP growth by sector allowed us to recover important intersector dynamics. The dynamic structure of our model is fairly simple and highlights the main lines of causality. However, we have to keep in mind that the industrial, agricultural and service sectors represent themselves as aggregates. There may well exist a much more complex dynamic structure at the intrasector level that might be diffused or even eliminated through sector aggregation.

In the next section we, therefore, present the evidence of bivariate cointegration tests between the different intrasector components as defined in Table 1. This might enable us to gain further insight into the inter and intrasector growth dynamics of Ecuador and provide us with important information for further model building.

\subsection{Intersector and Intrasector Dynamics}

In order to explore inter- as well as intrasector dynamics, we perform a recursive cointegration analysis between different sector components. This allows us to establish evidence for cointegration while at the same time addressing the issue of stability of the cointegration relationship. We exclude the time period from 1965 to 1972 , prior to the oil nationalisation, from the analysis and use the period from 1973 to 1982 as the base period for our recursive cointegration analysis. The graphical plots of the trace-statistics for the different bivariate cointegration tests are reported in Figures 1 to 9 in the appendix. To save space we only report a selection of the recursive cointegration tests. ${ }^{9}$

The findings widely confirm the multivariate cointegration analysis of the last section. We find that over the full sample the agricultural sector cointegrates with manufacturing, commerce, transport and public services. The fact that the agricultural sector cointegrates directly with most other sectors is interesting, since agriculture is generally assigned a low degree of forward and backward linkages and thus rarely seen as

\footnotetext{
${ }^{9}$ The other graphs are available from the authors upon request.
} 
a key sector for economic development (Chenery and Watanabe (1958) and Hirschman (1961)).

However, the recursive analysis also reveals that the trace test for cointegration is not rejected in all investigated subsamples. In line with the earlier results, a stable longrun relationship seems only to form from around 1990 onwards.

Figure 3: Recursive Trace test for cointegration between agricultural and manufacturing sector GDP (1973 - 1998)

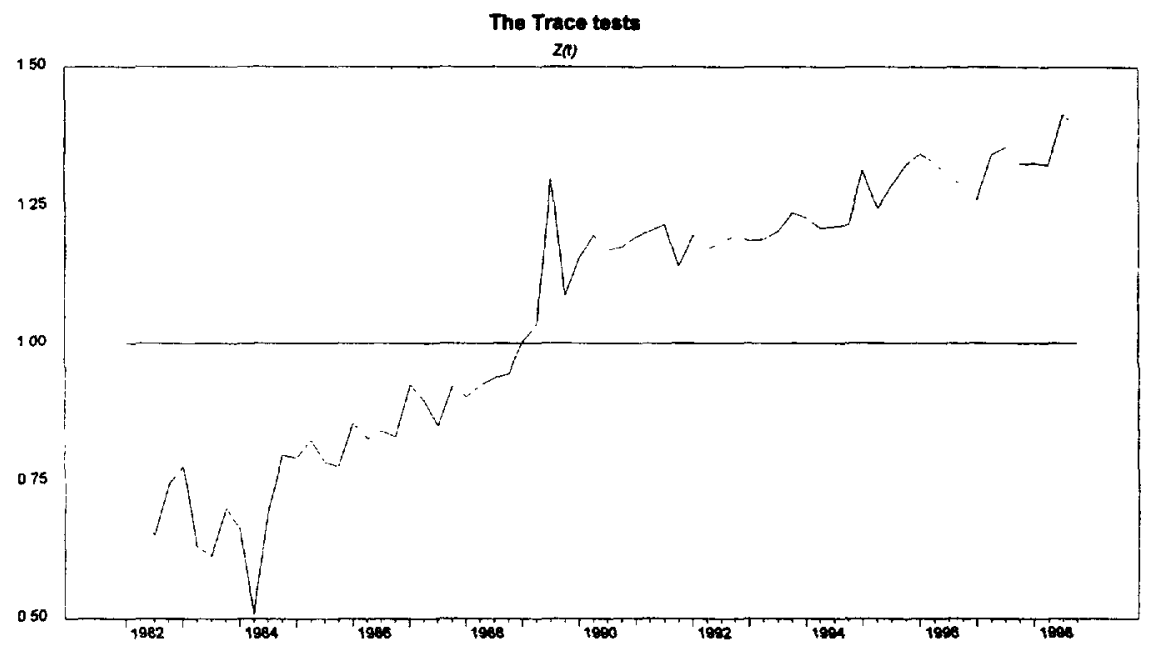

Source: Authors' calculations.

Of interest is also the development of the trace test for cointegration between the agricultural sector and public services. The null hypothesis of no cointegration is rejected from 1987 onwards which is much earlier than for the other cases.

For the manufacturing sector, the picture is even more interesting. While the graphical plots of the trace tests again seem to point to more stability between the sector components towards the end of the sample, the trace test for cointegration between the manufacturing and public sectors is rejected over the full sample, indicating a stable longrun relationship between these two variables.

The fact that there also appears to be a stable cointegration relationship between oil and public services is perhaps not such a surprising finding, given the importance of the oil revenues for the economy of Ecuador. 
Since there appears to be a general tendency for more stability towards the end of the sample, we also perform bivariate cointegration analyses for 1990:Q1 to 1998:Q4. The results of these tests are summarised in Table 9. The identified cointegration relationships seem to broadly support the findings of the recursive cointegration analysis over the larger sample and further indicate that the agricultural sector is well interlinked with the other sector components. Another interesting result of Table 9 is that there appears to be no direct link between the oil sector and the non-oil industrial sector. There is however, strong evidence for cointegration between the oil industry and financial services as well as between the oil industry and public services. Since financial services and public services are well interlinked with most other sector components, this underlines that we cannot exclude the oil sector from an intersector growth analysis since an adverse shock to the oil industry might affect the other sectors via the financial and/or the public sector.

Table 9: 1990Q1 - $1998 Q 4$

\begin{tabular}{|c|c|c|c|c|c|c|c|}
\hline & Oil & Agri. & Manu. & Constr. & Transp. & Com. & Finance \\
\hline Agriculture & 14.71 & & & & & & \\
\hline Manufacturing & 15.35 & $27.71^{* *}$ & .. & & & & \\
\hline Construction & 10.21 & 14.61 & $23.20^{* *}$ & & & & \\
\hline Transport & $28.77^{* *}$ & $19.66^{*}$ & $44.61 * *$ & 14.59 & & & \\
\hline Commerce & 16.32 & $28.11^{* *}$ & $26.01^{* *}$ & 10.67 & $26.75^{* *}$ & & \\
\hline Finance & $20.70^{* *}$ & $22.73 * *$ & $18.80^{*}$ & 13.16 & $19.97^{* *}$ & $18.26^{*}$ & \\
\hline $\begin{array}{l}\text { Public } \\
\text { Services }\end{array}$ & $34.96^{* *}$ & $29.56^{* *}$ & $36.95^{* *}$ & 14.75 & $32.30 * *$ & $33.12 * *$ & $40.60^{* *}$ \\
\hline
\end{tabular}


Further research will have to combine the different sector components within a multivariate analysis to explore the different inter- and intrasector dynamics to a fuller extent. $^{10}$

\section{Conclusion}

This paper explores whether the experience of Ecuador since 1965 supports the dual economy model based on an empirical analysis of the sectoral components in growth in GDP. While we find evidence for a long-run relationship between the different sectors from 1965 to 1998 , the relationship only proves stable from the end of the 1980 s onwards.

Our findings point to a large degree of interdependence in sectoral growth. Moreover, we identify the agricultural sector as a major driving force in sectoral growth in Ecuador. We take the latter point as evidence against the basic dual economy model, which implies that a long-run relation cannot exist between agricultural and industrial output. When discussing future agricultural development in Ecuador, it might be therefore useful to keep Chile's experience in mind, which demonstrates the importance of high value added agricultural activities for economic development.

One other interesting finding of our study is the impact of the oil industry on the recent economic development of Ecuador. While there appears to be no direct link between the oil sector and the non-oil industrial sector, the oil industry cointegrates directly with financial, as well as public services. Since financial and public services cointegrate directly with most other sector components, we cannot rule out important indirect links between the oil industry and other sectors. Thus, the often advocated practice to a priori exclude the oil sector from economic analyses may be too shortsighted. Furthermore, a multivariate cointegration analysis between all sector components of an economy would allow us to directly map the inter- and intrasector growth dynamics of an economy. This is left for future research.

\footnotetext{
${ }^{10}$ As a first step in this direction, in Table A5 we present the results of a multivariate cointegration analysis which combines all 7 sector components. At the $1 \%$ level of significance we find up to 3 significant cointegration vectors, indicating a fairly complex dynamic structure between the intrasector components.
} 


\section{Appendix 1: The Multivariate Cointegration Analysis of Johansen}

The Johansen procedure allows us to test for cointegration in a multivariate system. Starting from an unrestricted vector autoregressive model (VAR), the hypothesis of cointegration is formulated as a hypothesis of reduced rank of the long run impact matrix $\Pi$ (Johansen, 1988, Johansen and Juselius, 1990). The VAR is generated by the vector $\mathrm{z}_{\mathrm{t}}$, which defines the potential endogenous variables of the model. Taking first differences of the variables, the VAR can be transformed into an error correction model

$$
\Delta \mathrm{z}_{\mathrm{t}}=\Gamma_{1} \Delta \mathrm{z}_{\mathrm{t}-1}+\ldots+\Gamma_{\mathrm{k}-1} \Delta \mathrm{z}_{\mathrm{t}-\mathrm{k}=1}+\Pi \mathrm{z}_{\mathrm{t}-\mathrm{k}}+\psi \mathrm{D}_{\mathrm{t}}+\varepsilon_{\mathrm{t}}, \quad \varepsilon_{\mathrm{t}} \sim \mathrm{IN}(0, \Sigma)
$$

where the estimates of $\Gamma_{i}=-\left(I-A_{1}-\ldots-A_{i}\right),(i=1, \ldots, k-1)$ describe the short run dynamics to changes in $\mathrm{z}_{\mathrm{t}}$ and $\Pi=-\left(I-A_{1}-\ldots-A_{i}\right)$ captures the long run adjustments and $D$ contains deterministic terms.

Cointegration occurs in the case of reduced rank of $\Pi$. Only if the rank is reduced $(r<n)$ is it possible to factorise $\Pi$ into $\Pi\left(=\alpha \beta^{\prime}\right)$ where $\alpha$ denotes the adjustment coefficients and $\beta$ the cointegration vectors. The cointegration vectors $\beta$ have the property that $\beta^{\prime} \mathrm{z}_{t}$ is stationary even though $z_{t}$ itself is non-stationary.

If the rank is reduced it is possible to interpret the VAR in first differences as a vector error correction model and to obtain estimates of $\alpha$ and $\beta$ via the reduced rank regression. Since the rank of $\Pi$ is equal to the number of independent cointegration vectors and the rank of $\Pi$ is also equal to the number of non-zero eigenvalues, the test of cointegration thus amounts to a test for the number of non-zero eigenvalues. The trace statistics, $\lambda_{\text {trace, }}$ is a non-standard distributed likelihood-ratio test, which is commonly used to determine the number of cointegration vectors, (Johansen, 1988). The trace statistic tests the null hypothesis that there are at most $r$ cointegration vectors:

$$
H_{0}: \lambda_{i}=0, \text { for } \mathrm{i}=\mathrm{r}+1, . . \mathrm{n}
$$

where only the first $r$ eigenvalues, $\lambda$, are non-zero against the unrestricted hypothesis that $\mathrm{r}=\mathrm{n}$.

11 The null hypothesis of at most $r$ cointegration vectors implies that there are $n-r$ unit roots and, theoretically, $n-r$ zero eigenvalues. This is because the hypothesis of cointegration is formulated as the reduced rank of $\Pi=\alpha \beta^{\prime}$ and the full rank of $\alpha_{\perp}^{\prime} \Gamma \beta_{\perp}$, where $\alpha$ and $\beta$ are $n \times r$ matrices and $\alpha_{\perp}$ and $\beta_{\perp}$ are $\mathrm{n} \times(n-r)$ matrices orthogonal to $\alpha$ and $\beta$. This allows us then to distinguish between $r$ cointegrating $\mathrm{I}(0)$ relations and $n-r$ non-cointegrating $\mathrm{I}(1)$ relations. 
Appendix 2: Table A1: Rank test (1965 - 1998)

\begin{tabular}{lllll}
\hline The trace test & & & \\
\hline $\mathrm{r}$ & $\mathrm{p}-\mathrm{r}$ & Model 2 & Model 3 & Model 4 \\
0 & 3 & 45.838 & 34.086 & 49.340 \\
1 & 2 & $13.575^{*}$ & 5.849 & 19.181 \\
2 & 1 & 4.023 & 0.246 & 5.584
\end{tabular}

*Rank test is the first time not rejected at the $95 \%$ critical level of 19.96 , indicating a one cointegration vector and a constant in the cointegration space. Source: Authors' calculations.

Table A2: ADF Unit root tests: 1965 - 1998

\begin{tabular}{|c|c|c|}
\hline & Level & $I^{3}$ Difference \\
\hline \multicolumn{3}{|l|}{ Agr } \\
\hline ADF-test statistic: & -0.48 & -5.79 \\
\hline Lags: & (3) & (1) \\
\hline Ljung-Box: & $Q^{*}=39.35, p=0.21$ & $Q^{*}=40.47, p=0.17$ \\
\hline \multicolumn{3}{|l|}{ Ind } \\
\hline$A D F$-test statistic: & -2.23 & -7.53 \\
\hline Lags: & $(2)$ & $(1)$ \\
\hline Ljung-Box: & $\mathrm{Q}^{*}=14.45, \mathrm{p}=0.98$ & $Q^{*}=13.52, p=0.99$ \\
\hline \multicolumn{3}{|l|}{ Ser } \\
\hline ADF-test statistic: & -2.71 & -3.05 \\
\hline Lags: & (3) & $(2)$ \\
\hline Ljung-Box: & $Q^{*}=19.93, p=0.96$ & $Q^{*}=20.75, p=0.95$ \\
\hline
\end{tabular}


Table A3: Model specification for cointegration analysis between Agr, Ind, Ser: 1965 - 1998 ( 4 lags)

\begin{tabular}{|c|c|c|c|c|c|}
\hline \multicolumn{3}{|c|}{ Multivariate Statistics: } & & & \\
\hline \multicolumn{3}{|c|}{ Information Criteria } & & & \\
\hline & \multirow{2}{*}{-22.62} & & & \\
\hline \multicolumn{2}{|l|}{ HQ } & & & & \\
\hline \multicolumn{2}{|l|}{ Autocorrelation } & \multirow[b]{2}{*}{$\chi^{2}(261)=303.0$} & & & \\
\hline \multicolumn{2}{|l|}{ Ljung-Box (33) } & & & & \\
\hline $\mathrm{LM}(1)$ & & $\begin{array}{r}\chi^{2}(9)=11.86 \\
p \text {-value }=0.22\end{array}$ & & & \\
\hline \multicolumn{2}{|l|}{$\operatorname{LM}(4)$} & $\begin{array}{l}\chi^{2}(9)=13.58 \\
p \text {-value }=0.14\end{array}$ & & & \\
\hline \multicolumn{2}{|l|}{ Normality } & $\begin{aligned} \chi^{2}(6) & =73.51 \\
\text { p-value } & =0.00\end{aligned}$ & & & \\
\hline \multicolumn{6}{|c|}{ Univariate Statistics } \\
\hline & Skewness & Kurtosis & ARCH(4) & Normality & $\mathrm{R}^{2}$ \\
\hline Agr & -0.341027 & 5.056860 & 24.136 & 19.076 & 0.348 \\
\hline Ind & 0.226208 & 3.366645 & 21.896 & 2.339 & 0.397 \\
\hline Ser & 0.677302 & 6.982159 & 16.138 & 38.215 & 0.359 \\
\hline
\end{tabular}

Source: Authors' calculations.

Table A4: Model specification for cointegration analysis between Agr, Ind, Ser: 1990 - 1998 (2 lags)

Multivariate Statistics:

Information Criteria

SC

HQ

$-24.39$

Autocorrelation

Ljung-Box (8)

$-25.01$

$$
\chi^{2}(54)=68.87
$$

$\mathrm{p}$-value $=0.08$

LM(1)

$\chi^{2}(9)=8.419$

LM(4)

$\mathrm{p}$-value $=0.49$

$\chi^{2}(9)=10.281$

Normality

$\mathrm{p}-$ value $=0.33$

Univariate Statistics

$$
\begin{aligned}
\chi^{2}(6) & =7.104 \\
\text { p-value } & =0.31
\end{aligned}
$$

\begin{tabular}{llllll}
\hline & Skewness & Kurtosis & ARCH(2) & Normality & $\mathrm{R}^{2}$ \\
Agr & 0.169361 & 2.939815 & 4.400 & 0.716 & 0.255 \\
Ind & -0.694892 & 3.047675 & 0.319 & 3.637 & 0.368 \\
Ser & 0.605993 & 3.318944 & 2.009 & 2.602 & 0.383 \\
\hline
\end{tabular}

Source: Authors' calculations. 
Table A5: Multivariate Cointegration Analysis between the Variables of Table 9:

\begin{tabular}{ccllll}
\hline $\begin{array}{l}\text { Null } \\
\text { Hypothesis }\end{array}$ & $\begin{array}{l}\text { Alternative } \\
\text { Hypothesis }\end{array}$ & $\begin{array}{l}\text { Lag: } 2 \\
\text { With Constant }\end{array}$ & $\begin{array}{l}99 \% \\
\text { Critical Values }\end{array}$ & $\begin{array}{l}95 \% \\
\text { Critical Value }\end{array}$ & $\begin{array}{l}90 \% \\
\text { Critical Value }\end{array}$ \\
\hline$\lambda_{\text {trace }}$ test & & & & & \\
$r=0$ & $r>0$ & $224.75^{* *}$ & 177.20 & 165.58 & 159.48 \\
$r \leq 1$ & $r>1$ & $160.82^{* *}$ & 143.09 & 131.70 & 126.58 \\
$r \leq 2$ & $r>2$ & $111.84^{* *}$ & 111.01 & 102.14 & 97.18 \\
$r \leq 3$ & $r>3$ & $75.72^{*}$ & 84.45 & 76.07 & 71.86 \\
$r \leq 4$ & $r>4$ & 50.29 & 60.16 & 53.12 & 49.65 \\
$r \leq 5$ & $r>5$ & 31.26 & 41.07 & 34.91 & 32.00 \\
$r \leq 6$ & $r>6$ & 14.33 & 24.60 & 19.96 & 17.82 \\
$r \leq 7$ & $r>7$ & 1.71 & 12.97 & 9.24 & 7.52 \\
\hline
\end{tabular}

${ }^{* *}$ Significant at the $1 \%$ level, ${ }^{*}$ significant at the $5 \%$ level.

Source: Authors' calculations.

Fig. A1: Recursive trace test for cointegration between agricultural and commercial service sector GDP (1973 - 1998)

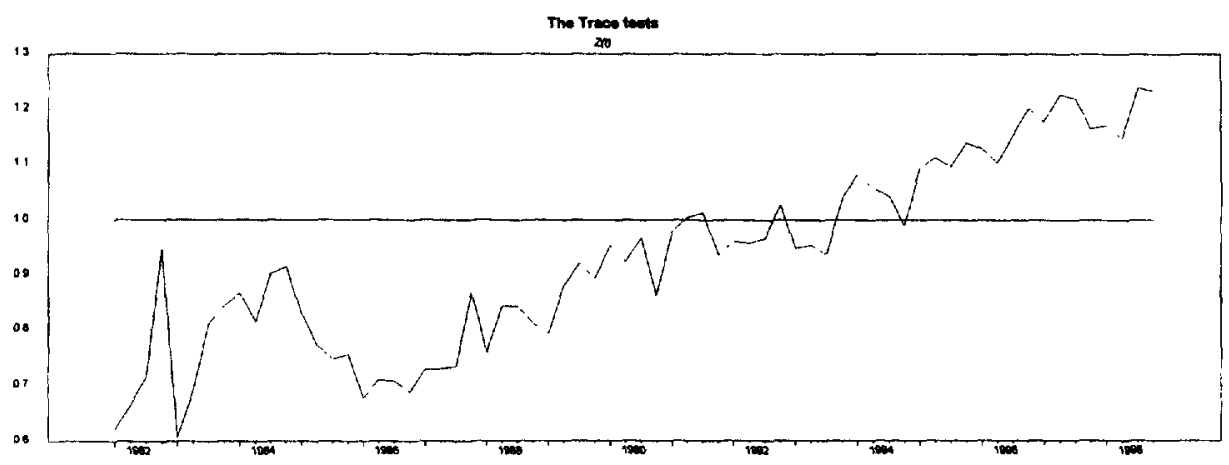

Fig. A2: Recursive trace test for cointegration between agricultural and transportation service sector GDP (1973 - 1998)

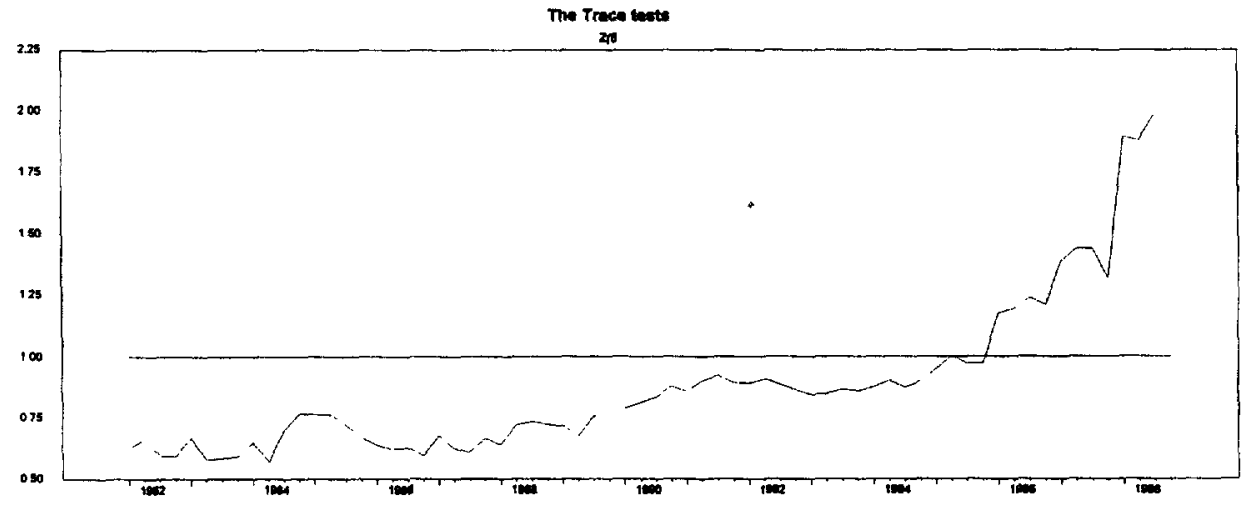


Fig. A3: Recursive trace test for cointegration between manufacturing and financial service sector GDP (1973 - 1998)

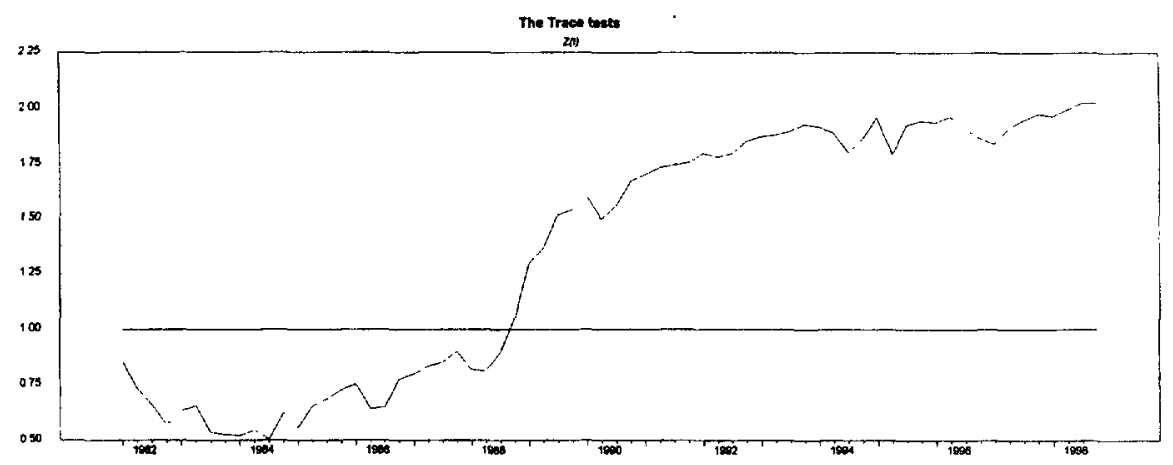

Fig. A4: Recursive trace test for cointegration between manufacturing and commercial service sector GDP (1973 - 1998)

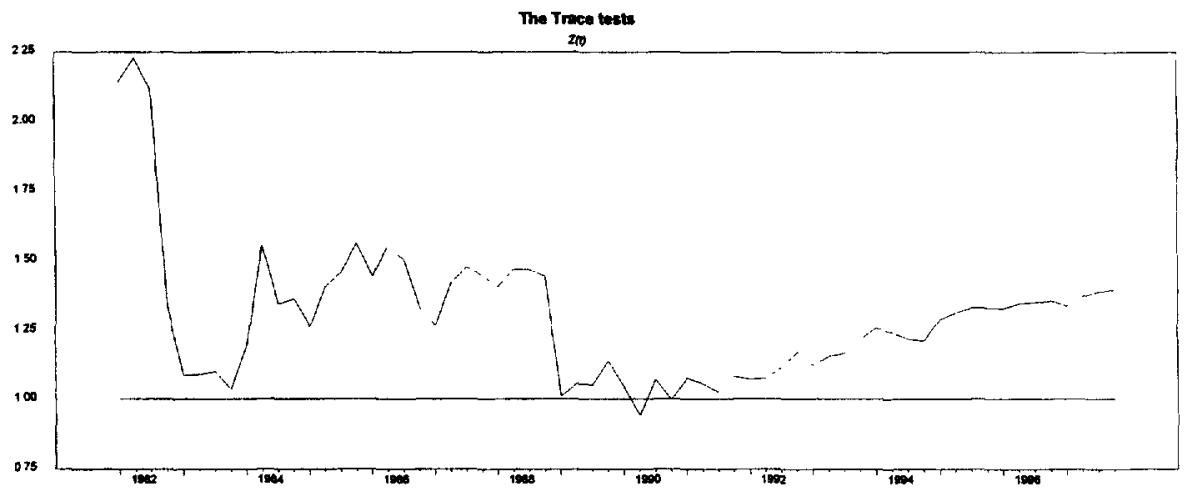

Fig. A5: Recursive trace test for cointegration between manufacturing and transportation service sector GDP (1973 - 1998)

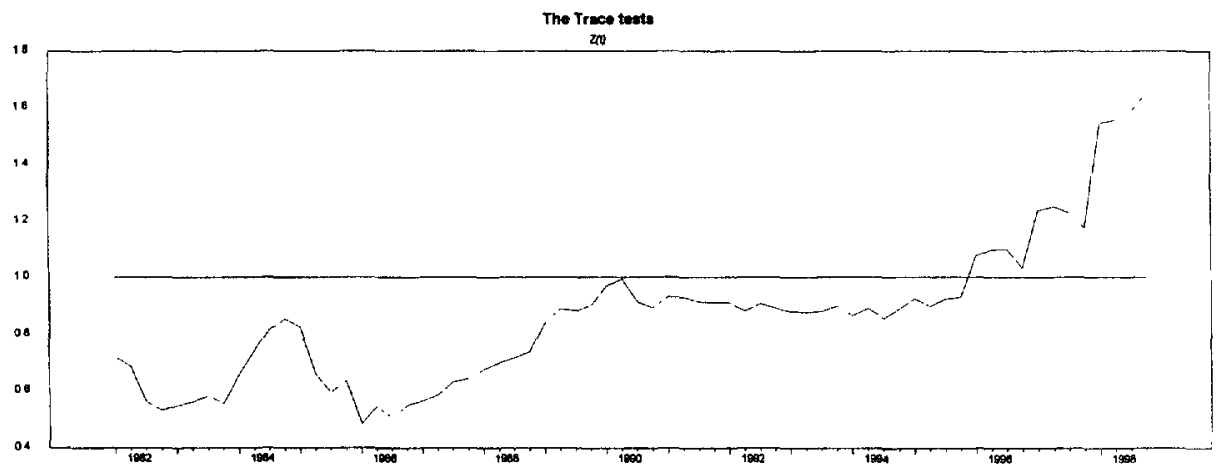


Fig. A6: Recursive trace test for cointegration between agricultural and public service sector GDP (1973 - 1998)

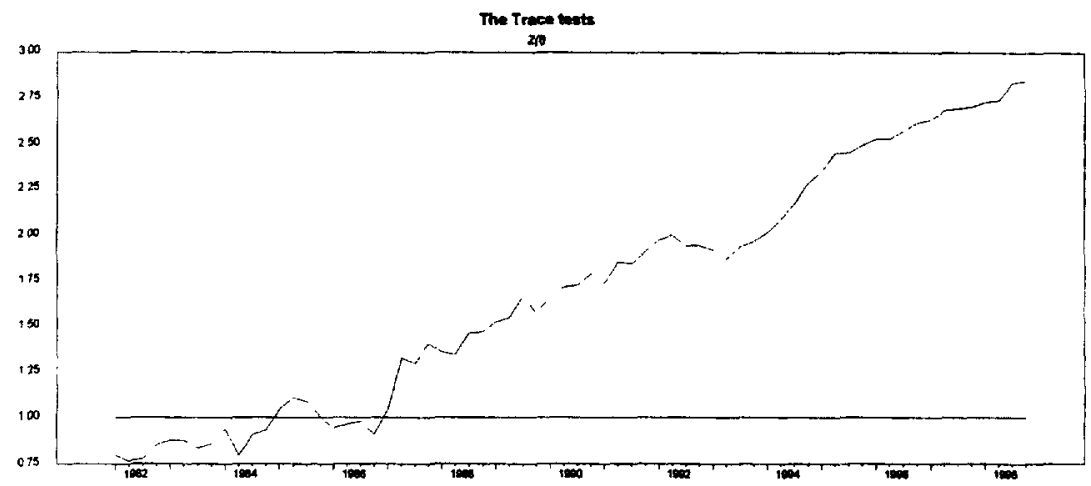

Fig. A7: Recursive trace test for cointegration between manufacturing and public service sector GDP (1973 - 1998)

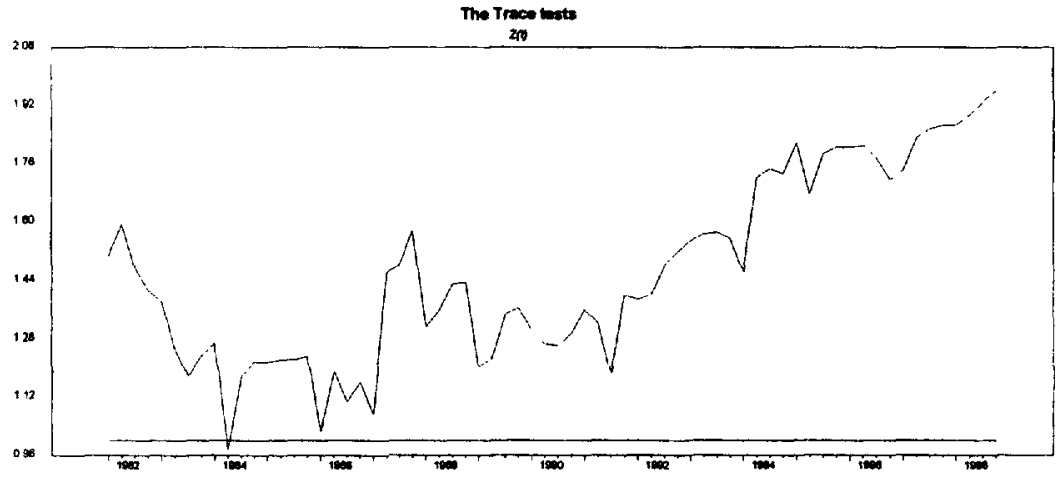

Fig. A8: Recursive trace test for cointegration between oil and public service sector GDP $(1973-1998)$

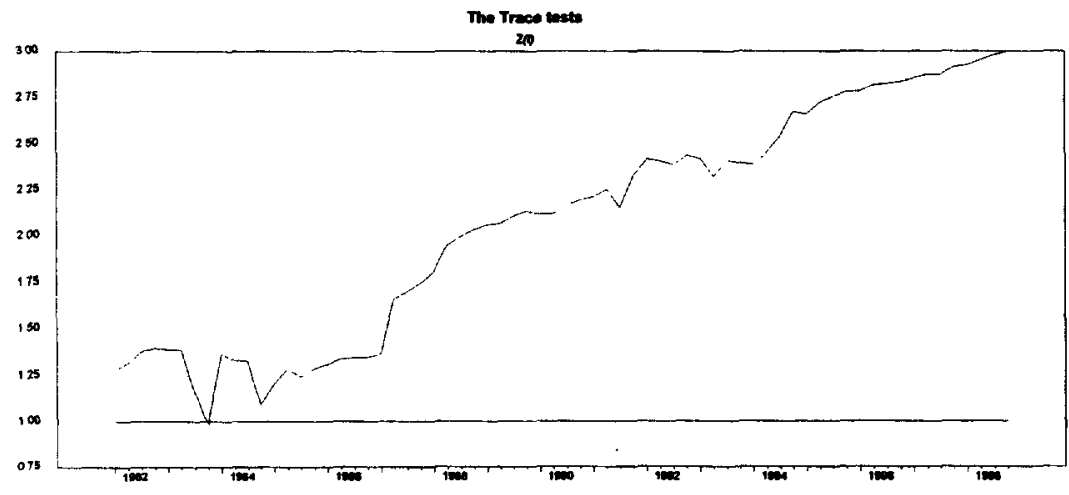




\section{Appendix 3:}

The World Bank Latinamerican and Caribbean Regional Database contains data on annual real GDP from 1965-98 for Ecuador. Since this data base could have been alternatively used for our cointegration analysis, we also perform a cointegration analysis using this data base. This allows us to contrast the results of a cointegration analysis based on annual data with the results of a cointegration analysis based on quarterly data. Since cointegration is a long-run property, the frequency of the data should not matter and we would expect to find similar results.

The results of the cointegration analysis with annual sectoral GDP data from the World Bank Latinamerican and Caribbean Regional Database indicate one cointegration relationship and thus confirm the results of our cointegration analysis based on the quarterly data base of the Banco del Ecuador.

\section{Table A6:}

\begin{tabular}{lllll}
\hline $\begin{array}{l}\text { Null } \\
\text { Hypothesis }\end{array}$ & $\begin{array}{l}\text { Alternative } \\
\text { Hypothesis }\end{array}$ & $\begin{array}{l}\text { Lag: 3 } \\
\text { With Constant }\end{array}$ & $\begin{array}{l}95 \% \\
\text { Critical } \\
\text { Value }\end{array}$ & $\begin{array}{l}90 \% \\
\text { Critical Value }\end{array}$ \\
\hline $\begin{array}{l}\lambda_{\text {trace }} \text { test } \\
\mathrm{r} \leq 0\end{array}$ & $\mathrm{r}>0$ & $38.49 *$ & 35.10 & 31.88 \\
$\mathrm{r} \leq 1$ & $\mathrm{r}>1$ & 14.66 & 20.17 & 17.79 \\
$\mathrm{r} \leq 2$ & $\mathrm{r}>2$ & 4.83 & 9.10 & 7.50 \\
\hline
\end{tabular}


Table A7: ECUADOR: MERCHANDISE TRADE

\begin{tabular}{|c|c|c|c|c|c|c|}
\hline & 1990 & 1992 & 1994 & 1996 & 1997 & $\overline{1998}$ \\
\hline Merchandise exports (FOB):* & 2724 & 3102 & 3843 & 4900 & 5264 & 4203 \\
\hline $\begin{array}{l}\text { Primary and semi-processed } \\
\text { goods: }\end{array}$ & 2617 & 2924 & 3476 & 4373 & 4708 & 3663 \\
\hline Oil and oil derivatives: & 1418 & 1345 & 1305 & 1776 & 1557 & 923 \\
\hline Crude oil & 1268 & 1260 & 1185 & 1521 & 1412 & 789 \\
\hline Oil derivatives & 150 & 86 & 120 & 255 & 146 & 134 \\
\hline Bananas and plantains & 471 & 683 & 708 & 973 & 1327 & 1070 \\
\hline Coffee and coffee products: & 130 & 82 & 414 & 160 & 121 & 105 \\
\hline Coffee & 104 & 61 & 366 & 129 & 92 & 72 \\
\hline Processed coffee & 26 & 21 & 48 & 30 & 30 & 33 \\
\hline Shrimp & 340 & 542 & 551 & 631 & 886 & 872 \\
\hline Cacao and cacao products: & 131 & 75 & 102 & 164 & 132 & 47 \\
\hline Cacao & 75 & 36 & 66 & 91 & 60 & 19 \\
\hline Processed cacao & 56 & 39 & 35 & 73 & 72 & 28 \\
\hline Fish and sea products: & 88 & 107 & 187 & 291 & 307 & 351 \\
\hline Tuna & 13 & 30 & 21 & 59 & 69 & 61 \\
\hline Fish & 34 & 26 & 52 & 26 & 30 & 22 \\
\hline Fishmeal & 9 & 7 & 10 & 54 & 23 & 13 \\
\hline Other processed sea products & 32 & 44 & 105 & 152 & 185 & 255 \\
\hline Hemp & 8 . & 7 & 11 & 15 & 15 & 13 \\
\hline Wood & 0 & 8 & 20 & 29 & 38 & 23 \\
\hline Natural flowers & 14 & 30 & 59 & 105 & 131 & 162 \\
\hline Other primary products & 17 & 44 & 119 & 230 & 194 & 97 \\
\hline Manufactured products: & 107 & 177 & 366 & 527 & 556 & 540 \\
\hline Chemicals and pharmaceuticals & 12 & 17 & 32 & 46 & 51 & 57 \\
\hline Metal manufactures & 14 & 34 & 119 & 109 & 142 & 130 \\
\hline Hats & 8 & 6 & 8 & 5 & 5 & 4 \\
\hline Textile manufactures & 6 & 19 & 41 & 52 & 61 & 52 \\
\hline Other manufactured products & 68 & 101 & 166 & 315 & 296 & 298 \\
\hline Merchandise imports (FOB): & 1647 & 1977 & 3209 & 3571 & 4520 & 5110 \\
\hline Consumption goods: & 160 & 321 & 715 & 779 & 948 & 1080 \\
\hline Consumer durables & 97 & 138 & 304 & 459 & 563 & 660 \\
\hline Consumer non-durables & 63 & 183 & 411 & 319 & 385 & 420 \\
\hline Fuels and lubricants & 69 & 75 & 78 & 122 & 379 & 273 \\
\hline Intermediate goods: & 860 & 817 & 1157 & 1586 & 1796 & 1991 \\
\hline Agricultural & 73 & 97 & 114 & 219 & 246 & 247 \\
\hline Industrial & 707 & 652 & 957 & 1221 & 1393 & 1572 \\
\hline Construction materials & 80 & 68 & 86 & 145 & 157 & 171 \\
\hline Capital goods: & 554 & 761 & 1259 & 1083 & 1396 & 1766 \\
\hline Agricultural & 24 & 20 & 31 & 34 & 43 & 51 \\
\hline Industrial & 341 & 440 & 596 & 698 & 918 & 1108 \\
\hline Transport & 189 & 301 & 632 & 351 & 435 & 607 \\
\hline Other imports & 4 & 2 & $\mathbf{0}$ & 1 & 1 & 1 \\
\hline
\end{tabular}

Source: Informacion Estadistica Mensual, Septiembre 30 de 1999, Banco de Ecuador.

*: In thousands of dollars. 


\section{Bibliography}

Blunch, N.-H.; Verner, D. (1999): Sector Growth and the dual economy model: evidence from Côte d'Ivoire, Ghana and Zimbabwe, Policy Research Working Paper No. 2175, The World Bank.

Chenery, H.B.; Watanabe, T. (1958): International comparisons of the structure of production, Econometrica.

Cheung, Y.-W., Lai, K. S. (1993): Finite sample sizes of Johansen's likelihood ratio tests for cointegration, Oxford Bulletin of Economics and Statistics, 55,3, 313-328.

Gopinath, M.; Roe, T.L; Shane, M.D. (1996): Competitiveness of U.S. Food processing: benefits from primary agriculture, American Journal of Agricultural Economics, 78, $4,1044-55$.

Hendry, D.F.; Mizon, G.E. (1993): Evaluating dynamic econometric models by encompassing the VAR, in: P.C.B. Phillips (ed.): Models, methods and applications of econometrics: Essays in honor of A.R. Bergstrom (Blackwell: Oxford, 1993).

Hentschel, J. (1994): Trade and Growth in Ecuador: A partial equilibrium analysis, Policy Research Working Paper No. 1352, The World Bank.

Hirschman, A.O.; (1959): The strategy of economic development, New Haven, Conn.: Yale University Press.

Johansen, S. (1988): Statistical analysis of cointegration vectors, Journal of Economic Dynamic and Control, 12, 231-254.

Johansen, S.; Juselius, K. (1990): Maximum likelihood estimation and inference on cointegration. With applications to the demand of money, Oxford Bulletin of Economics and Statistics, 52, p.169-210.

Johansen, S.; Juselius, K. (1992): Testing structural hypothesis in a multivariate cointegration analysis of PPP and the UIP for UK, Journal of Econometrics, 53, p.169209.

Johnston, B,; Kilby, P. (1975): Agriculture and structural transformation: Economic strategies in late developing countries, London: Oxford Press.

Krueger, A.; Schiff, M.; Valdes, A. (1992): The political economy of agricultural pricing policy: a synthesis of the economics of developing countries. Baltimore, Md: John Hopkins University Press.

Lewis, W.A.; (1954): Economic development with limited supplies of labour, Manchester School of Social Science, 22, 139-91. 
Marconi, S.; Samaniego, p. (1995): Las fuentes del crecimiento economico: una perspectiva a partir de la demanda, Notas Technicas 19, Banco Central del Ecuador.

Martin, W.; Mitra, D. (1998): Productivity growth and convergence in agriculture and manufacturing, Development Research Group, World Bank., and Dept. of Economics, Florida International University, Washington., D.C. and Miami., Fla.

Mellor, J.; Lele, U (1973): Growth linkages of the new food grain technologies, Indian Journal of Agricultural Economics, 18 (1).

Mellor, J. (1976): The new economics of growth: A strategy for India and the developing World, Ithaca, N.Y.: Cornell University Press.

Michaely, M. (1999): The Andean Group: Ecuador's trade and commercial policies, mimeo.

Osterwald-Lenum, M. (1992): A note with quantiles of the asymptotic distribution of the maximum likelihood cointegration rank test statistics, Oxford Bulletin of Economics and Statistics, 54, 3, 461- 473. 


\section{Policy Research Working Paper Series}

Title

WPS2493 Annuity Markets in Comparative Perspective: Do Consumers Get Their Money's Worth?

WPS2494 The Relevance of Index Funds for Pension Investment in Equities

WPS2495 The Australian Annuity Market

WPS2496 Perspectives on the Sources of Heterogeneity in Indian Industry

WPS2497 State Policies and Women's Autonomy in China, India, and the Republic of Korea, 1950-2000: Lessons from Contrasting Experiences

WPS2498 Sustaining Economic Welfare: Estimating Changes in Per Capita Wealth

WPS2499 The Treatment of Non-Essential inputs in a Cobb-Douglas Technology: An Application to Mexican Rural Household-Level Data

WPS2500 Investigating Corruption

WPS2501 Anti-Corruption Policies and Programs: A Framework for Evaluation

WPS2502 Implications of the Currency Crisis for Exchange Rate Arrangements in Emerging East Asia

WPS2503 Proposed Strategy for a Regional Exchange Rate Arrangement in Post-Crisis East Asia

WPS2504 Social Capital and the Quality of Government: Evidence from the United States
Author

Estelle James

Dimitri Vittas

Ajay Shah

Kshama Fernandes

David M. Knox

Somik V. Lall

G. Chris Rodrigo

Monica Das Gupta

Sunhwa Lee

Patricia Uberoi

Danning Wang

Lihong Wang

Xiaodan Zhang

Kirk Hamilton

Isidro Soloaga

Canice Prendergast

Jeff Huther

Anwar Shah

Masahiro Kawai

Shigeru Akiyama

Masahiro Kawai

Shinji Takagi

Stephen Knack
Date

Contac:

for pape:

November 2000

A. Yaptenco 31823

November 2000

A. Yaptenco 31823

November 2000

A. Yaptenco 31823

November 2000

R. Yazigi 37176

November 2000

M. Das Gupia 31983

November 2000

L. Rivera 82819

December 2000

L. Tabada 36896

December 2000

H. Sladovich 37698

December 2000

A. Santos 31675

December 2000

A. Azarcon 36049

December 2000

A. Azaicon 36049

December 2000

P. Sintin-Aboesye 38526 


\section{Policy Research Working Paper Series}

\section{Title}

WPS2505 Family Altruism and Incentives

WPS2506 Ethnicity and Wage Determination in Ghana

WPS2507 Public Expenditures and Environmental Protection: When is the Cost of Funds Irrelevant?

WPS2508 Sources of Financial Assistance for Households Suffering an Adult Death in Kagera, Tanzania

WPS2509 How Tax Policy and Incentives Affect Foreign Direct Investment: A Review

WPS2510 Environmental Protection and Optimal Taxation

WPS2511 Monetary Policy under Flexible Exchange Rates: An Introduction to Inflation Targeting

WPS2512 Quantifying the Impact of Technical Barriers to Trade: A Framework for Analysis

\section{Author}

Roberta Gatti

Abigail Barr

Abena Oduro

Gunnar S. Eskeland

Mattias Lundberg

Mead Over

Phare Mujinja

Jacques Morisset

Neda Pirnia

Gunnar S. Eskeland

Pierre-Richard Agénor

Keith E. Maskus John S. Wilson Tsunehiro Otsuki
Date

December 2000

December 2000

December 2000

December 2000

December 2000

December 2000

December 2000

December 2000
N. Busjeet 33997

\section{Contact} for paper

R. Bonfield 31248

R. Bonfield 31248

H. Sladovich 37698

V. Soukhanov 35271

H. Sladovich 37698

M. Gosiengfiao 33363

L. Tabada 36896

M. Leon 36151

Private Participation in the Water Sector?

Evidence from Côte d'Ivoire, the Gambia,

Guinea, and Senegal 